\title{
THE APPLICATIONS ON SOME INEQUALITIES OF THE COMPOSITION OF ENTIRE FUNCTIONS
}

\author{
HONG-YAN XU, Jin TU AND CAI-FENG Yi
}

Abstract. The purpose of our paper is to deal with some growth problem of two composite entire functions of finite $[p, q]$-order and some properties of growth of $f \circ g, f$ and $g$. Some results are obtained as follows: Let $f, g$ be two entire functions and have index-pair $\left[p_{1}, q_{1}\right],\left[p_{2}, q_{2}\right]$, respectively. Let $f \circ g$ have index-pair $\left[p_{3}, q_{3}\right]$. Then we have the following conclusions:

(i) if $p_{2}+1-q_{1}>0$, then $p_{3}=p_{1}+p_{2}-q_{1}+1 \Longleftrightarrow q_{3}=q_{2}$;

(ii) if $p_{2}+1-q_{2}=0$, then $p_{3}=p_{1} \Longleftrightarrow q_{3}=q_{2}$;

(iii) if $p_{2}+1-q_{1}<0$, then $p_{3}=q_{1} \Longleftrightarrow q_{3}=q_{1}+q_{2}-p_{2}-1$.

These results are some improvement and generalization of the form theorems given by Gross, Lahiri, Tu.

Mathematics subject classification (2010): 30D30, 30D35.

Keywords and phrases: Entire function, composition, infinite order.

\section{REFERENCES}

[1] W. BergweILER, On the growth rate of composite meromorphic functions, Complex Var. Elliptic Equ., 14 (1990), 187-196.

[2] W. BERGWEILER, Order and lower order of composite meromorphic functions, Michigam Math. J., 36 (1989), 135-146.

[3] J. Clunie, The Composition of Entire and Meromorphic Functions, Mathematical Essays Dedicated to A. J. Macintyre, Ohio University Press, 1970, pp. 75-92.

[4] F. GRoss, Factorization of meromorphic function, U.S. Government Printing office, Washington D.C., 1972.

[5] W. K. Hayman, Meromorphic functions, Oxford at the Clarendon Press, 1964.

[6] O. P. JuneJA, G. P. KAPOOR AND S. K. BAJPAI, On the $(p, q)$-order and lower $(p, q)$-order of an entire function, J. Reine Angew. Math., 282 (1976), 53-67.

[7] O. P. Juneja, G. P. KAPOOR AND S. K. BAJPAI, On the $(p, q)$-type and lower $(p, q)$-type of an entire function, J. Reine Angew. Math., 290 (1977), 180-190.

[8] L. Kinnunen, Linear differential equations with solutions of finite iterated order, Southeast Asian Bull. Math., 22 (4) (1998), 385-405.

[9] L.-W. LiAO AND C.-C. YANG, On the growth of composite entire functions, Yokohama Math. J., 46 (1999), 97-107.

[10] J. LIU, J. TU AND L.-Z. SHI, Linear differential equations with entire coefficients of $[p, q]$-order in the complex plane, J. Math. Anal. Appl., 372 (1) (2010), 55-67.

[11] K. Nilino And N. Smita, Growth of a composite function of entire functions, Kodai Math. J., 3 (1980), 374-379.

[12] K. NIINO AND C.-C. YANG, Some growth relationships on factors of two compositive entire functions, in: Factorization Theory of Meromorphic functions and Related Topics, Marcel Dekker Inc., New York/Basel, 1982, pp. 95-99.

[13] G. Pólya, On an integral function of an integral function, J. London. Math. Soc., 1 (1926), 12-15.

[14] A. SchÖNHAGE, Über das Wachstum Zusammengesetzter Funktionen, Math. Z., 73 (1960), 22-44.

[15] A. P. SingH, Growth of composite entire functions, Kodai Math. J., 8 (1985), 99-102. 
[16] A. P. Singh, On maximum term of composition of entire functions, Proc. Nat. Acad. India, 59 (1989), $103-115$.

[17] J. Tu, Z.-X. Chen AND X.-M. Zheng, Composition of entire functions with finite iterated order, J. Math. Anal. Appl., 353 (2009), 295-304.

[18] L. YANG, Value distribution theory, Springer-Verlag, Berlin, 1993.

[19] H.-X. YI AND C.-C. YANG, Uniqueness theory of meromorphic functions, Science Press/Kluwer Academic Publishers, Beijing/New York, 1995/2003.

[20] Z.-Z. ZHOU, Growth of composite entire functions, Kodai Math. J., 9 (1986), 419-420. 